\title{
ECONOMIC DIVERSIFICATION: AN INSIGHT INTO SUSTAINABLE AND INCLUSIVE AGRICULTURE WITH SPECIAL REFERENCE TO PAKISTAN
}

\author{
Dixit Pankaj ${ }^{\star}$, Assistant Professor \\ Department of Accounting and Finance, Lebanese French University, \\ Kurdistan Region, Iraq \\ ORCID: 0000-0002-1334-8837
}

Lal R.C., Professor, Dean (Research)

Department of Commerce and Business Administration, C.C.S. University, Meerut, India

\author{
Yadav Arvind Kumar, Dr., Head of Department \\ Department of Commerce, KM. Mayawati Government Girls College, Badalpur, India \\ ORCID: 0000-0003-1835-9655
}

*E-mail: pankajdixit@lfu.edu.krd

\begin{abstract}
Crop diversification is an important step to deal with the challenges of present and future faced today by agriculture economies. Population explosion in agriculture economies surpassed carrying capacity of resources so endangering inclusion. Our research on economic diversification and government reform measure particularly in agriculture is to deal with sustainability of agriculture economy like Pakistan. The main objective of this paper is to analyze how economic diversification and land reform can prove to be a milestone in tackling the challenges faced by agriculture economy. In order to perform numerical and qualitative analysis of primary and secondary data, the analysis is shown through the SPSS Software. As a result, it was known that through diversification and land reforms, Pakistan's agricultural economy will be strengthened. At the end of the paper, some effective suggestion regarding inclusive agriculture model have been given, which will be important in achieving the said objectives.
\end{abstract}

\section{KEY WORDS}

Economy diversification, inclusive growth, food security, agricultural diversification, farming.

Economic diversification is the method of shifting focus from monopolizes economy to diversify economy of varied sectors and markets. Historically, it's been applied as a method to encourage positive economic process and development. Within the context of greenhouse effects due temperature change suitable adaptation and mitigation practices require. Economic diversification covers all sector of economy with equality. It encourages inclusion and development of every aspect such that trade deficit can be eliminated, its work on selfsufficiency and resourcefulness in every kind of situation. Diversification encourages using low carbon footprint sector, which are less emissive and sustainable for environment. A lot of climate resilient technology has develops today that can increase financial gain in long term in sustainable manner. Shifting from one sector to another for gaining the advantage of diversifies opportunities in employment generation and value addition is necessity today. Diversification is a continuous process for dynamic economic situations. Diversification is grabbing the opportunities through monitoring the scenario of economy sectors volatility and implementing the required action accordingly. Diversification creates an impact among the different sectors of economy. The government should not focus on one sector only instead it should diversify its focus on different sectors to achieve the desired objective to achieve sustainable economic growth. Sudden changes in the economy create the impact globally, like the changes in price of crude oil by the dominated countries will create an effect on 
global market. Sudden downfall in the crude Oil prices will effects the oil based economy and creates financial crisis.

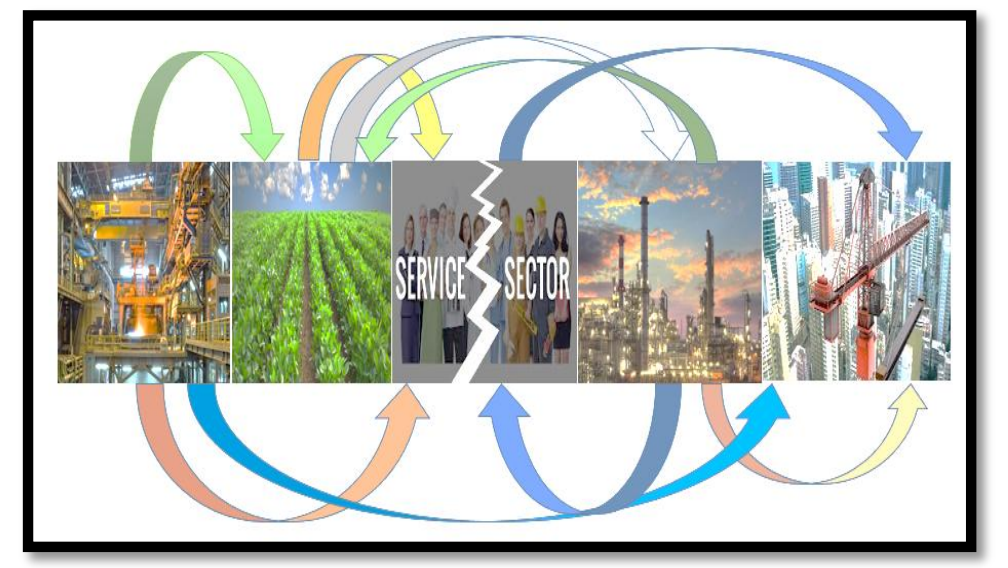

Figure 1 - Economic Diversification (Source: Authors compilation)

Note: Figure 1 shows that about diversification of sectors from oil to service, oil to agriculture, agriculture to manufacturing, agriculture to service and vice-versa

Pakistan is the South Asian developing country with a population of 207 million; it is sixth largest populous country but its ranked 38th in rate of GDP. Agriculture is prime moving force in Pakistan's economy as growth is concern; traditional agricultural practices with obsolete technology responsible for stagnant growth. Agriculture contributes a substantial part about $18.9 \%$ in GDP of Pakistan; and also among the major earner of foreign exchange reserve through export. Subsequently, agriculture contributes a great role in the financial inclusion of the nation.

According to Pakistan bureau of statistics, labor force survey report 2017-18 reveals that $38.5 \%$ of the total workforce employed in the agriculture sector. Approximately $64 \%$ population of Pakistan is directly or indirectly depends on agriculture. Agriculture and allied sector also support cottage industries, dairying and food industries. It's a high remunerative sector in term of agricultural export. Agriculture also plays a major role in livestock development that supports dairying sector and meat production. It does also fulfill protein necessity in diet that provides a healthy lifestyle to people of Pakistan. Thus, it is evident from above fact that agriculture plays a multi-dimensional role in the economy of Pakistan. Hence it is called an agricultural based economy. But as per GDP statistics contribution of agriculture is decreasing since 1947. It's become third largest sector from largest contributor of GDP. Its mean greater part of population depend on $18 \%$ of GDP, which indicates lower per capita income, highly financial divisive society and lower purchasing power of majority of population. Lower purchasing power results in stagnant industrial sector. Majority of the population is facing nutritional insecurity, unemployment and stagnant growth in every sector of economy $[1,2]$.

Pakistan has two agro climatic seasons, "Kharif" being the first sowing season beginning from April-June and is harvested in October-December. Rice, sugarcane, cotton, maize, moong, mash, bajra and jowar are major "Kharif" crops. "Rabi", the second sowing season, starts in October-December and is harvested in April-May. Wheat, gram, lentil (masoor), tobacco, rapseed, grain and mustard are "Rabi" crops. Mono-cropping agriculture in Pakistan are playing vital role in terms of mass agriculture production but in terms of food security nutritional security is lacking in food basket of its people.

This paper tries to find the problem and solution of Pakistan agriculture through the crops diversification with reforms in the agriculture sector. The assumptions of this paper are the agricultural Diversification can change the picture of Pakistan agriculture through seasonal crops diversification from existing mono-cropping to multi-cropping methods and securing traditional variety of crops for maintaining genetic diversification of crops that is indigenous. Others reform includes timely cheap credit access, corporate investment 
opportunity as Corporate Agribusiness practices and Crops Diversification includes low remunerative to high remunerative crops, Less nutritive to multi-nutrition value crops and Import substitutive production. The present government focusing on quantitative agriculture growth but the demand today is qualitative production needed for nutritional security. Qualitative production is possible through reforms and diversification on micro-level and sublevel $[3,4]$.

\section{Objective of the Research:}

- To find out the reason behind the backwardness of Pakistan's agriculture;

- To know what are the current and future challenges of food security in Pakistan and how to deal with it;

- To know how diversification can enable Pakistan agricultural progressive and move forward;

- To know what is the flaw in the current Corporate Agriculture Farming policy and how it can be overcome;

- To know how agriculture diversification and land reforms will help in achieving the goal of inclusive growth;

- To find out which model schemes will help to overcome the problems.

This research used both qualitative and quantitative data, it is collected by the researcher from published reports of Government and Non-government agency, research papers, conducted Personal interviews of respondents, panel discussion with economist and open discussion on social networking websites. For critical analysis the data, the SPSS software is used reflecting mean, standard deviation, frequency, percentage.

\section{RESULTS AND DISCUSSION}

Generally, the Economy of Pakistan is divided into three major sectors.

Primary: Agriculture is the primary and traditional sector of economy; it is playing a major role in the employment of Pakistan as well as in GDP, it includes important Crops, Other crops, Cotton Ginning Livestock, poultry, Forestry and Fishing. According to Pakistan economic survey 2017-18 agriculture share in GDP is $18.86 \%($ Figure 2) and of total workforce employed in this sector is $42.3 \%$ (Figure 3) [5].

Secondary: Manufacturing and industry are the secondary segments of economy, processing of raw material in final output by human activity included in this sector. Secondary sector included Automotive, Electrical industry, Chemical Industry, Energy industry (according to some sources it is on the border of the tertiary sector), Metallurgical industry, Construction Industry, Food Industry, Glass industry, Textile and clothing industry and Consumer goods industry (all consumables). Currently, industry sector contributes $20.91 \%$ (Figure 2) and of total workforce employed in this sector is $22.60 \%$ (Figure 3).

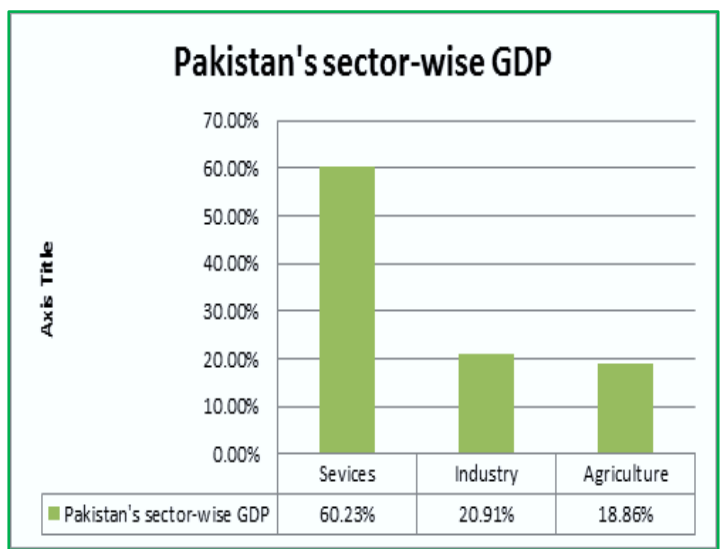

Figure 2 - Pakistan's sector-wise GDP (Source: Pakistan Bureau of Statistics)

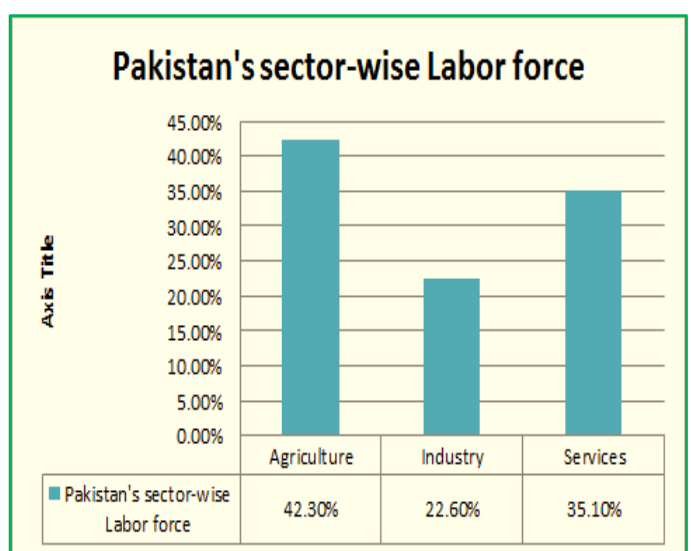

Figure 3 - Pakistan's sector-wise labor force (Source: Pakistan Bureau of Statistics) 
Tertiary: sector covers services provided by human efforts, like works, Knowledge consultancy, Engineering services, Finance Work, Business Knowledge Process Outsourcing, etc. This sector is tertiary but the contribution of this sector to GDP is $60.23 \%$ (Figure 2) and this sector is second largest employer after agriculture. Currently, $35 \%$ of total workforce is employed in this sector (Figure 3) [6].

Figure 2 shows the Sector wise GDP contribution of Pakistan economy, in which contribution of service, industry and agriculture are $60.23 \%, 20.91 \%$ and $18.86 \%$.

Figure 3 reveals the sector wise workforce data of Pakistan, in which $42.3 \%$ workforce engaged in agriculture, $22.60 \%$ people employed in industry and $35.1 \%$ people employed in service sector.

Statement of the problem in Pakistan Agriculture Pakistan has highly fertile agriculture land for its domestic food requirement and exports as well, but due to lack of dynamic reforms its leads to stagnant agriculture output. Land reforms are still awaited so that the 'welfare soul of the Pakistan' constitution towards inclusive growth is too far from the ground reality. Reforms in agriculture are the need of every nation. Diversified policy can balance the agriculture growth positively. Pakistan agriculture is more concentrated on major crops besides its ignoring the production of horticultural and cash crops like vegetables, fruits and other fibre crop. Pakistani vegetable growers are losing against Indian counterpart by losing foreign reserve as trade deficit across Wahga border. Their rivals are growing vegetables at abundant lower price as they avail subsidies from their government. There are abundant possibilities that the vegetable sector of West Pakistan might lose its identity and ultimately reach to an irretrievable stage if not properly managed by government initiatives such as subsidies intervention, incentives promotion etc. Inflation management through import substitution is not a sustainable solution for future of agriculture. At present, the current news report reveals that Pakistan and India relations are suffering due to cross border terrorism conflict. After the Pulwama terror attack, Indian vegetables producer's banned the export to Pakistan so that Tomato and other vegetables prices are going to high in Pakistan. Diversifying agricultural growth is need of present according to current economic situation. Concentration on major crops production, Import of agriculture products, Exclusive development policies like existing Corporate Agriculture Farming and Pending land reforms are the barrier in inclusive growth of Pakistan.

Needs of Reforms and Diversification for Pakistan's Agriculture. Inclusive growth is a challenge for Pakistan government; currently the present government is trying to achieving it through reforms in agriculture

Importance of Internal-Diversification for Pakistan:

- Food security is a major concern for Pakistan, Diversification will give value addition to nutritious Food production;

- Increase in income of farmers through diversify high value crops production;

- It will help to eliminate the problem of terrorism in unemployed youngster section of the society;

- Diversify crops production (from two seasonal to multi-seasonal crops) also good for soil fertility;

- Help to control food inflation and also minimize the risk of financial and economic crisis;

- It will also minimize the current account deficit problem of the country.

Pakistan's economy is looking for a very rapid progress which requires recurring changes on the on number of levels. Today, Pakistan two main challenges are poverty and food security. For this, the development should sustainable rather than temporary. For inclusive growth of Pakistan, diversification the economy is should be focus for policy makers. Today, increasing unemployment, terrorism, and growing discontent in the lower classes are the major problems facing by the Pakistani government. Due to unemployment, some youths are exclude from main stream of development and forced to joining terrorist organization for securing their part of bread. This is right time for Pakistan government to make specific modern policies for targeted areas in the agricultural sector. Any sector of the economy cannot move beyond reforms. There is a need of improvement on many levels, it is 
necessary to classify them into various segments as high, medium, low and subtle and infinitesimally points.

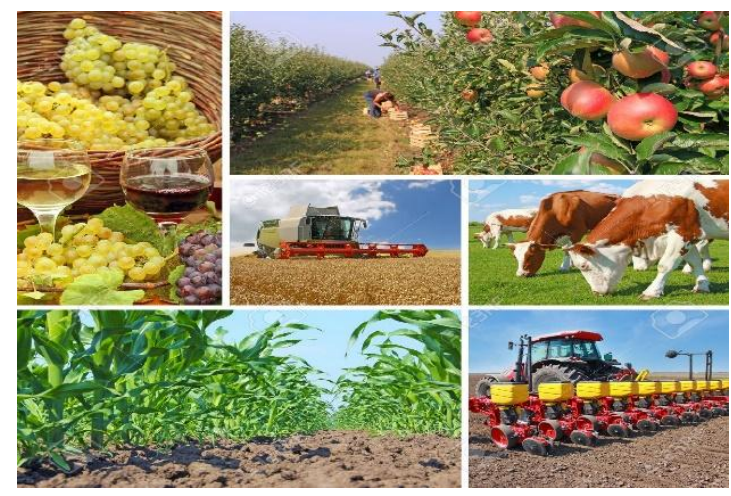

Figure 4 - Agriculture diversification (Source: Millions of Millions of Creative Stock Photos 123rf.com) Note: Figure 4 showing the agriculture products diversification from one product to another different products

It is the diversification within agriculture sector (Intra- Diversification). Internal diversification is the need of world because rapid increase in the population of countries leads to rise in challenges of the food security all over the world. So, Diversification inside the agriculture is the need of today world.

Agriculture diversification is the need of world because rapid increase in the population of countries leads to rise in challenges of the food security all over the world. So, Diversification inside the agriculture is the need of today world as shown in Figure 4.

It can be categorized in following manner:

- Crops to crops diversification;

- livestock to livestock diversification;

- Crops to live stock diversification;

- Livestock to crops diversification;

- Seasonal Diversification (Rabi and Kharif to multi-seasonal crops diversification);

- Credit scheme diversification;

- Diversification in crops area of production;

- Investment diversification is also important for Corporate Farming Policy in Pakistan.

Potential of Diversification. Diversification is generally a two way of process just like opportunity cost concept; if the one part is on downfall then the other part have the potential to create the opportunity, but the challenge is how we can grab this opportunity it is so important for government. If the one crop/product is suffering due to higher production and lower prices then we can shift our workforce into another beneficial substitute crops. Economy environment is dynamic in nature, this dynamic nature create negative problem as well opportunity.

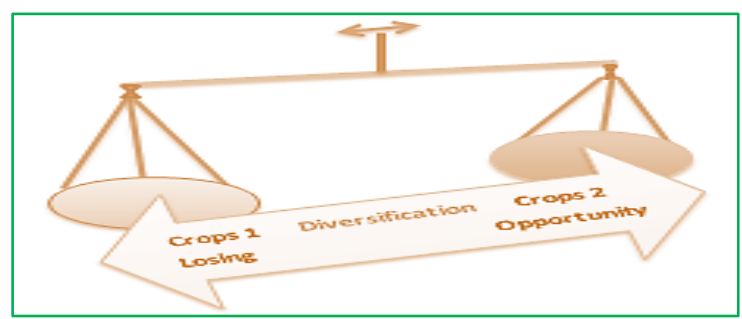

Figure 5 - Potential of Diversification Source (Source: Authors compilation)

Note: Figure 5 showing the opportunity Libra, in which one crop is losing the price or demand but other crops giving alternative opportunity

Crop diversification. Diversification of crop is important for many economies in many ways. It is beneficial in resolving the main problems like food security, inclusive growth, and 
soil fertility. Along with domestic needs, food security of other countries can be overcome through diversification. Food security is a challenge for Pakistan's rapidly growing population for policy makers. High value crops are beneficial to increase the income of farmers; also the challenge of malnutrition can be tackled by diversification of the crops. Mono-cropping consume higher input include fertilizer, water, pesticide, insecticide etc. so less remunerative. Diversification of crop products provides high production and high remuneration to the farmers due low input and sustains the fertility [7].

Table 1 - Agriculture Growth Percentages (Base=2005-06)

\begin{tabular}{|c|c|c|c|c|c|c|c|c|c|}
\hline Sector & $2011-12$ & $2012-13$ & $2013-14$ & $2014-15$ & $2015-16$ & $2016-17$ & $2017-18(\mathrm{P})$ & $\begin{array}{c}\text { Mean } \\
\Sigma^{2} \sum \mathrm{Xi}^{\prime}\end{array}$ & $\begin{array}{c}\text { S.D } \\
\sigma \overline{\mathrm{X}}\end{array}$ \\
\hline Agriculture & 3.62 & 2.68 & 2.5 & 2.13 & 0.15 & 2.07 & 3.81 & 2.422857 & 1.2114415 \\
\hline Crops & 3.22 & 1.53 & 2.64 & 0.16 & -5.27 & 0.91 & 3.83 & 1.002857 & 3.05325899 \\
\hline i)Important Crops & 7.87 & 0.17 & 7.22 & -1.62 & -5.86 & 2.18 & 3.57 & 1.932857 & 4.8717544 \\
\hline ii) Other Crops & -7.52 & 5.58 & -5.71 & 2.51 & 0.4 & -2.66 & 3.33 & -0.58143 & 4.8742364 \\
\hline iii)Cotton Ginning & 13.83 & -2.9 & -1.33 & 7.24 & -22.12 & 5.58 & 8.72 & 1.288571 & 11.823083 \\
\hline Livestock & 3.99 & 3.45 & 2.48 & 3.99 & 3.36 & 2.99 & 3.76 & 3.431429 & 0.5533964 \\
\hline Forestry & 1.79 & 6.58 & 1.88 & -12.45 & 14.31 & -2.37 & 7.17 & 2.415714 & 8.4260466 \\
\hline Fishing & 3.77 & 0.65 & 0.98 & 5.75 & 3.25 & 1.23 & 1.63 & 2.465714 & 1.863347 \\
\hline P: Provisional & & \multicolumn{8}{|c|}{ Source: Pakistan Bureau of Statistics } \\
\hline
\end{tabular}

Table 1 shows the growth rate of important crops and other crops. Stable growth concern is the need of Pakistan Economy but the standard deviation reveals that instability in overall performance of agriculture sector. Average Growth of other crops is decreasing as compare to important crops. From the point of food security this concept of important crops and others crops should be change.

Nutritious food is also the major concern in food security of Pakistan economy. Crops production should be balanced according to crops demand. Diversification of crops also helpful to control food inflation problem and can help to eliminate the poverty.

Table 2 - Crops Pattern - By Province

\begin{tabular}{|c|c|c|c|c|c|c|c|c|c|c|c|}
\hline $\begin{array}{c}\text { Administrative } \\
\text { Unit }\end{array}$ & Wheat & Rice & Maize & $\begin{array}{c}\text { Jowar/ } \\
\text { Bajra }\end{array}$ & Cotton & Sugarcane & $\begin{array}{c}\text { Oil } \\
\text { seeds }\end{array}$ & Pulses & Orchards & Fodders & Others \\
\hline & Pakistan & 42 & 14 & 4 & 2 & 14 & 4 & 2 & 5 & 2 & 9 \\
\hline $\begin{array}{c}\text { Khyber } \\
\text { Pakhtunkhwa }\end{array}$ & 47 & 3 & 24 & 3 & $*$ & 6 & 1 & 5 & 1 & 6 & 6 \\
\hline Punjab & 41 & 14 & 1 & 2 & 15 & 4 & 2 & 6 & 1 & 11 & 2 \\
\hline Sindh & 38 & 20 & $*$ & 2 & 20 & 5 & 3 & 1 & 2 & 4 & 5 \\
\hline Balochistan & 45 & 13 & 2 & 6 & 1 & ${ }^{*}$ & 4 & 4 & 10 & 3 & 11 \\
\hline
\end{tabular}

Table 2 data reveals that the unbalanced situation of crops area according to different crops. As compare to other nutritious crops wheat sowing area is $42 \%$ while pulses, fodders, sugarcane, orchards, oilseeds, and others are Total in $26 \%(5,9,4,2,2$, and 4$)$. This picture shows that disorganized planning for crops production. So, crops diversification should be implemented according to demand.

Beside of Rabi and Kharif crops, multi-seasonal crops can increase the production and income of farmers. In Pakistan, they have shortage of pulses, pulses are crucial for elevation the problem of food security.

Inter-diversification between Crop and livestock is the best mix combination strategy for rural households, who have less than 5 acres of land. This mix farming can increase the income of households as well as it is the best way to overcome the problem of food insecurity. Barley, pulses and green food crops, other high nutritious and high value crops are the most demanded crops that have abundant quantity for human nutrition and relics of these crops are also useful to feed the livestock. Dairy cattle product are full of nutrients so demand of these products are high in all over the world so it is also the best source of income for the rural households [8]. 
Corporate farming's objective is to maximize profit. To do so, the companies will invest in technology that may increase production (milk, corn, animals, etc.) moreover as lower inputs (feed, fertilizer, blighter management, etc.) moreover as minimize the inherent risks of farming. The advantage that they need over the smaller "family farm" is access to the technology. Corporate agriculture farming also facilitate keep your food bills from apace increasing additionally as it's certain that the ever increasing human population has food on the table.

Corporate Farming law was passed by Pakistan in 2001, under that listed companies might lease land within the country for ninety nine years, broken into 2 periods of fifty years and forty nine years. Besides, the then government had known state lands to lease. Corporate agriculture farming has taken over majority of the Pakistan agriculture share. Majority of agriculture land of Pakistan has been rented out or leased or sold out to foreign companies. United Arab Emirates and Saudi Arab is a big investor who invested the money in corporate agriculture farming. Millions of hectares land has been leased or sold out to corporate investors. Pakistan has divided its crops production in two sub segment; important crops and other crops. Existing policy depicts unbalanced picture of investment flow among all crops and livestock. Table 1 reveals that Instead of Existing CAG policy the agriculture growth of Pakistan is instable in nature, even in year 2014-2016 it was negative. This policy should be diversified, so Investment diversification is needed for corporate agriculture farming policy. Currently majority of the corporate firms have invested in major crops and poultry but other crops are suffering due to higher demands and less production. Corporate agriculture policy needs crops and product wise diversification of land [10].

For inclusive growth of the Pakistan, finance is among main input of agriculture productivity. Changing economic environment conditions create new opportunity for diversify production. We can distribute this diversify opportunity dividend between the rural poor people through the credit diversification policy with a view to achieve inclusive objective.

Table 3 - Agriculture Credit disbursement details of Pakistan

\begin{tabular}{|c|c|c|c|c|}
\hline $\mathrm{n} / \mathrm{n}$ & $2016-17$ & \% Share & $2017-18$ & \% Share \\
\hline Farm Credit & 196.1 & 47.9 & 260.8 & 45.8 \\
\hline Non-Farm Credit & 212.9 & 52.1 & 309.1 & 54.2 \\
\hline Small Farms & 74.7 & 35.1 & 92.1 & 29.8 \\
\hline Large Farms & 138.2 & 64.9 & 217 & 70.2 \\
\hline
\end{tabular}

Source: Pakistan Economic survey 2017-18.

Table 3 showing the agriculture credit disbursement between farm and non-farm and small farm and large farm details of Pakistan for 2016-17 and 2017-18.

At present the pro-poor credit disbursement policy of Pakistan is not up to the mark From the Table 3 it is clearly mentioned that Government credit disbursement for small farms is $29.8 \%$ of total. This following policy called "Diversify Crop credit and Insurance Scheme":

To compensate the risk factor default of farmers, in the case of climate based natural disaster and other loss this scheme will provide them crops risk cover, In 2008 Pakistan made mandatory crop loan insurance scheme, but this scheme is confine to five major crops i.e., wheat, cotton, rice, sugarcane and maize. According to this scheme, the small farmers who are having only up to 25

Acres of land will be benefitted from this scheme because this is mandatory in nature. For implementing this scheme government is contributing the cost of premium only $2 \%$.

Need of land reforms in Pakistan for inclusive growth. Pakistan has total 52.91 million acres land area for farming. According to geographical agriculture location, Pakistan is divided into four provinces; Khyber Pakhtunkhwa, Punjab, Sindh and Balochistan, the most important and largest geographical province is Punjab having 29.33 million acres farm area, it is playing dominantly role in the Pakistan agriculture economy as compare to other provinces. Sindh is second largest province having 9.87 million acres land after Balochistan and Khyber Pakhtunkhwa having 8.14 and 5.57 million acres farming area. 
Pakistan's agriculture economy can be called as farms economy because according to the assessments of Agricultural Census 2010, there were 8.26 million farms in the nation. These Agri-farms were working in the area of 52.91 million acres of land. Division of agriculture land among little and huge farms was exceptionally skewed. Farms having less than 5 acres of land had 64 percent (5.35 million) of absolute private farms, however they worked just 19 percent of the all-out farming part (10.18 million). Those, which were 25 acres or more of land having just 4 percent of the all farms ( 0.30 million), yet they have control of 35 percent of the all-out agrarian land (18.12 million acres). Average farms area in country was 6.4 acres of land and average cultivated area every farm was 5.2 acres.

Pakistan land reforms. Land reforms in Pakistan have a long and fairly checkered history. The British had less enthusiasm for the issue as they depended on the help of a few powerful proprietors. In spite of the fact, that there had been some restricted changes in the years paving the way to 1947, every real change date from the years after freedom. Very quickly the different commonplace lawmaking bodies passed a few rules whereby the jagirdari frameworks were abrogated and occupants secured. The real changes, be that as it may, came in three phases: the first amid Ayub Khan's military law in 1959; the second and third amid Zulfiqar Ali Bhutto's standard during the 1970s. These reforms imposed the ceiling on landholding to achieve the aim of inclusive growth.

Table 4 - Statistics of Questionnaire response

\begin{tabular}{|c|c|c|c|c|c|c|}
\hline & $\mathrm{n} / \mathrm{n}$ & $\begin{array}{c}\text { What is your } \\
\text { Profession? } \\
1\end{array}$ & $\begin{array}{c}\text { Internal diversification } \\
\text { of agriculture sector } \\
\text { can increase the GDP } \\
\text { of Pakistan } \\
2\end{array}$ & $\begin{array}{c}\text { Crop diversification } \\
\text { can increase the } \\
\text { income of farmers } \\
3\end{array}$ & $\begin{array}{c}\text { Crop diversification } \\
\text { is necessary for } \\
\text { food security and } \\
\text { soil fertility } \\
4\end{array}$ & $\begin{array}{l}\text { What are } \\
\text { the reasons } \\
\text { for rural } \\
\text { poverty? } \\
5\end{array}$ \\
\hline \multirow{2}{*}{$\mathrm{N}$} & Valid & 104 & 104 & 104 & 104 & 104 \\
\hline & Missing & 0 & 0 & 0 & 0 & 0 \\
\hline \multicolumn{2}{|r|}{ Mode } & 5.00 & 2.00 & 2.00 & 2.00 & 5.00 \\
\hline \multicolumn{2}{|c|}{ Minimum } & 1.00 & 1.00 & 1.00 & 1.00 & 1.00 \\
\hline \multicolumn{2}{|c|}{ Maximum } & 5.00 & 2.00 & 2.00 & 2.00 & 5.00 \\
\hline
\end{tabular}

Table 5 - Statistics of Questionnaire response

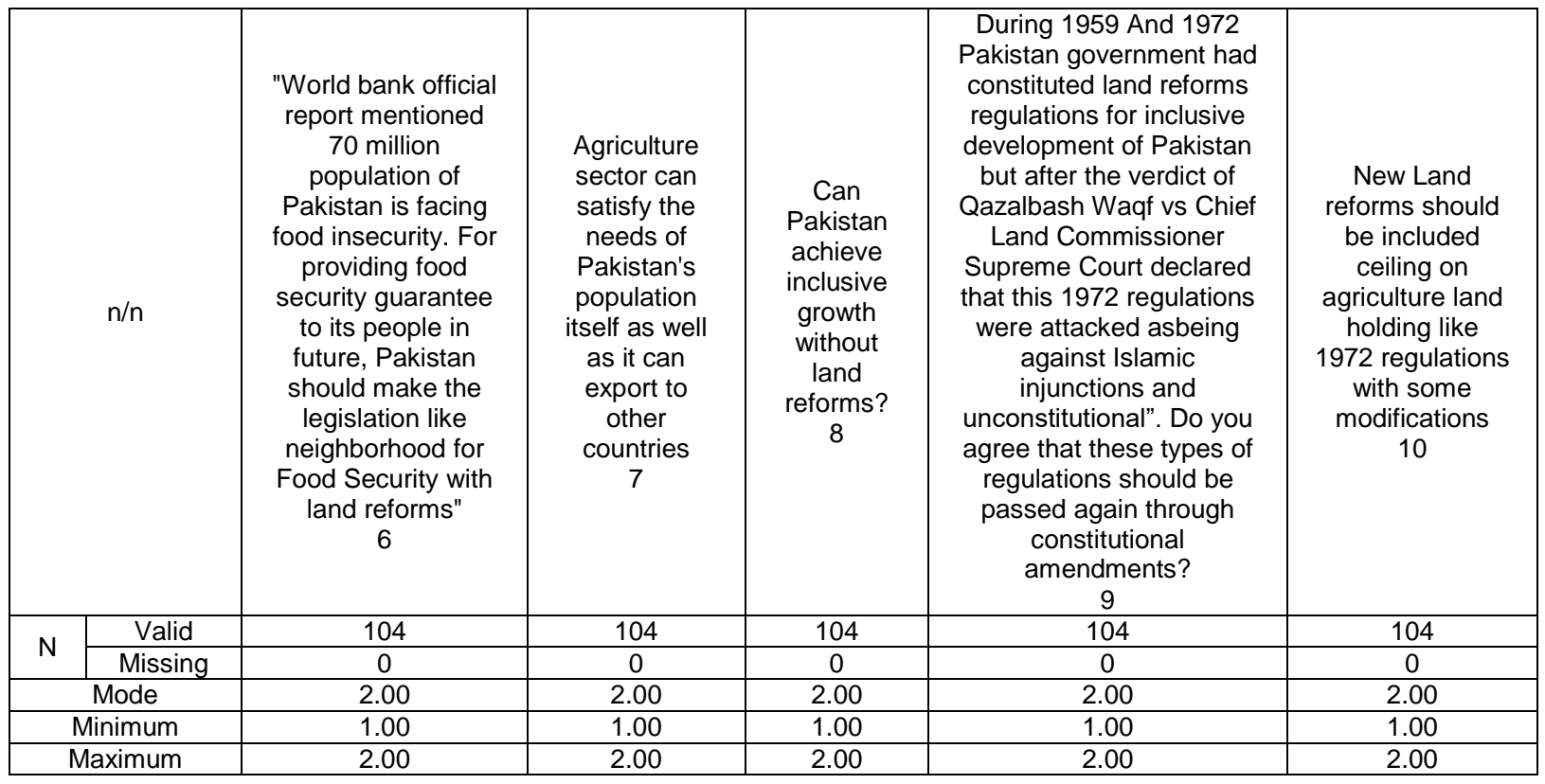

So these reforms in Land changes were constantly dubious. It was asserted by rivals that they were un-Islamic and that they encroached on the directly to claim, use and appropriate property as secured by the constitution. Matters at long last reached a crucial stage under the watchful eye of the Supreme Court on account of Qazalbash Waqf v Chief Land Commissioner in which both the 1972 directions were assaulted as being against 
Islamic orders and illegal. The Supreme Court concurred. Of the 1972 controls, the Supreme Court proclaimed that passages $7,8,9,10,13$ and 14 and hence thusly 18 were unlawful as being against Islamic directives. The striking down of sections 8 and 18 toppled the principle changes accomplished [11].

Table 6 - Statistics of Questionnaire response

\begin{tabular}{|c|c|c|c|c|}
\hline \multicolumn{2}{|c|}{$\begin{array}{c}\text { n/n } \\
\text { new land } \\
\text { reforms Land } \\
\text { ceiling should } \\
\text { be: } \\
11\end{array}$} & $\begin{array}{c}\text { Do you agree that the existing } \\
\text { Corporate agriculture farming policy is } \\
\text { a barrier to achieve inclusive growth } \\
\text { and food security, it should be change } \\
12\end{array}$ & $\begin{array}{c}\text { Do you agree that Government of Pakistan } \\
\text { should lease the agriculture land to own } \\
\text { landless rural people instead of giving to } \\
\text { Foreign corporate for inclusive growth } \\
13\end{array}$ \\
\hline \multirow{2}{*}{$\mathrm{N}$} & Valid & 104 & 104 & 104 \\
\cline { 2 - 5 } & Missing & 0 & 0 & 0 \\
\hline \multicolumn{2}{|c|}{ Mode } & 4.00 & 2.00 & 2.00 \\
\hline \multicolumn{2}{|c|}{ Minimum } & 1.00 & 1.00 & 1.00 \\
\hline \multicolumn{2}{|c|}{ Maximum } & 4.00 & 2.00 & 2.00 \\
\hline
\end{tabular}

Table 7 - Questionnaire response Analysis (Question mentioned in table 4, 5 and 6)

\begin{tabular}{|c|c|c|c|c|c|}
\hline Question & Response & Frequency & Percent & Valid Percent & Cumulative Percent \\
\hline \multirow{6}{*}{1} & Agriculturist/Farmer & 31 & 29.8 & 29.8 & 29.8 \\
\hline & Lawyers & 11 & 10.6 & 10.6 & 40.4 \\
\hline & Journalist & 5 & 4.8 & 4.8 & 45.2 \\
\hline & Social Activist/N.G.O Volunteer & 15 & 14.4 & 14.4 & 59.6 \\
\hline & Researcher from Economy's field & 42 & 40.4 & 40.4 & 100 \\
\hline & Total & 104 & 100 & 100 & \\
\hline \multirow{3}{*}{2} & $\mathrm{NO}$ & 11 & 10.6 & 10.6 & 10.6 \\
\hline & YES & 93 & 89.4 & 89.4 & 100 \\
\hline & Total & 104 & 100 & 100 & \\
\hline \multirow{3}{*}{3} & NO & 11 & 10.6 & 10.6 & 10.6 \\
\hline & YES & 93 & 89.4 & 89.4 & 100 \\
\hline & Total & 104 & 100 & 100 & \\
\hline \multirow{3}{*}{4} & NO & 7 & 6.7 & 6.7 & 6.7 \\
\hline & YES & 97 & 93.3 & 93.3 & 100 \\
\hline & Total & 104 & 100 & 100 & \\
\hline \multirow{6}{*}{5} & Asymmetrical distribution of Agriculture land & 7 & 6.7 & 6.7 & 6.7 \\
\hline & Lack of technical skills/T raining & 5 & 4.8 & 4.8 & 11.5 \\
\hline & Corporate Agriculture Farming policy & 7 & 6.7 & 6.7 & 18.3 \\
\hline & Poor crops finance scheme & 3 & 2.9 & 2.9 & 21.2 \\
\hline & All of the above & 82 & 78.8 & 78.8 & 100 \\
\hline & Total & 104 & 100 & 100 & \\
\hline \multirow{3}{*}{6} & NO & 6 & 5.8 & 5.8 & 5.8 \\
\hline & YES & 98 & 94.2 & 94.2 & 100 \\
\hline & Total & 104 & 100 & 100 & \\
\hline \multirow{3}{*}{7} & NO & 5 & 4.8 & 4.8 & 4.8 \\
\hline & YES & 99 & 95.2 & 95.2 & 100 \\
\hline & Total & 104 & 100 & 100 & \\
\hline \multirow{3}{*}{8} & NO & 25 & 24 & 24 & 24 \\
\hline & YES & 79 & 76 & 76 & 100 \\
\hline & Total & 104 & 100 & 100 & \\
\hline \multirow{3}{*}{9} & NO & 26 & 25 & 25 & 25 \\
\hline & YES & 78 & 75 & 75 & 100 \\
\hline & Total & 104 & 100 & 100 & \\
\hline \multirow{3}{*}{10} & NO & 30 & 28.8 & 28.8 & 28.8 \\
\hline & YES & 74 & 71.2 & 71.2 & 100 \\
\hline & Total & 104 & 100 & 100 & \\
\hline \multirow{5}{*}{11} & 50 Acres - 100 Acres & 7 & 6.7 & 6.7 & 6.7 \\
\hline & $100-150$ Acres & 8 & 7.7 & 7.7 & 14.4 \\
\hline & $150-200$ Acres & 15 & 14.4 & 14.4 & 28.8 \\
\hline & Between 200 - 500 Acres & 74 & 71.2 & 71.2 & 100 \\
\hline & Total & 104 & 100 & 100 & \\
\hline \multirow{3}{*}{12} & NO & 50 & 48.1 & 48.1 & 48.1 \\
\hline & YES & 54 & 51.9 & 51.9 & 100 \\
\hline & Total & 104 & 100 & 100 & \\
\hline \multirow{3}{*}{13} & $\mathrm{NO}$ & 24 & 23.1 & 23.1 & 23.1 \\
\hline & YES & 80 & 76.9 & 76.9 & 100 \\
\hline & Total & 104 & 100 & 100 & \\
\hline
\end{tabular}


Landless of rural population is concerned with inclusive development. It is clear from the report of the Statistics Department of Pakistan that the farmers who have less than 25 acres of agricultural land, their crops production are more than big landowners. So, Constitutional amendments are requiring for agriculture land reforms now.

From the prepared scheduled questionnaire, the above question asked by the researcher to targeted respondents through telephone, Social networking contacts, panel discussion and Personal interview, all the respondents were having the higher qualifications from the interdisciplinary research areas and the respondents 'are from different countries includes Pakistan, India, Bangladesh, Nigeria and Iraq. This study was focused on subject experts a total of 104 respondents. Table 4,5 and 6 related with statistics of all questions about minimum, maximum and mode of response are given.

Table 7 (Question 1) showing the participated respondent profession, out of which $29.8 \%$ are agriculturist, $10.6 \%$ are lawyers, $4.8 \%$ are journalist, $14.4 \%$ are Social activist from N.G.O and $40.4 \%$ are researchers from Economy field. $89.4 \%$ respondents agreed that internal diversification of agriculture can increase the GDP of Pakistan (Question 2) and the same percentage respondents were agree about crops diversification can increase the income of farmers (Question 3). Total 93.3\% respondents believe that crop diversification is necessary for food security and maintaining the fertile strength of the land (Question 4). In the response of the question about reasons for rural poverty, $78.8 \%$ people believe on all mentioned response but $21.2 \%$ of people had opinions in different ways, out of which the respondents $(7.8 \%$ asymmetric distribution of land, $4.8 \%$ lack the technical skill, $6.7 \%$ Corporate Agriculture Farming, and $2.8 \%$ poor crop finance scheme) consider the cause of rural poverty(Question 5). 94.3\% people agreed that Pakistan govt. should make the legislation for food security of its people (Question 6). 'Agriculture sector can satisfy the needs of Pakistan's population itself as well as it can export to other countries' $95.2 \%$ respondents agreed with this statement. Question 7 reveals that $79 \%$ respondents believe that Pakistan cannot achieve inclusive growth with land reforms. Majority of the respondents (more than 70\%) believe that Pakistan should make the legislation on land reforms like past regime through constitutional amendments and these legislation should have the ceiling on land holding( Question 8,9 and 10). Only 51.9\% respondents agreed that Corporate Agriculture Policy is barrier in inclusive growth (Question 11) and 76.9\% respondents believe that Pakistan govt. should lease the agriculture land to own landless rural people instead of giving to Foreign corporate for inclusive growth (Question 12 and 13).

\section{PROPOSED SUGGESTIONS}

On the basis of analysis from secondary data and primary data, following suggestion can be implemented to achieve the goal of inclusive growth and food security.

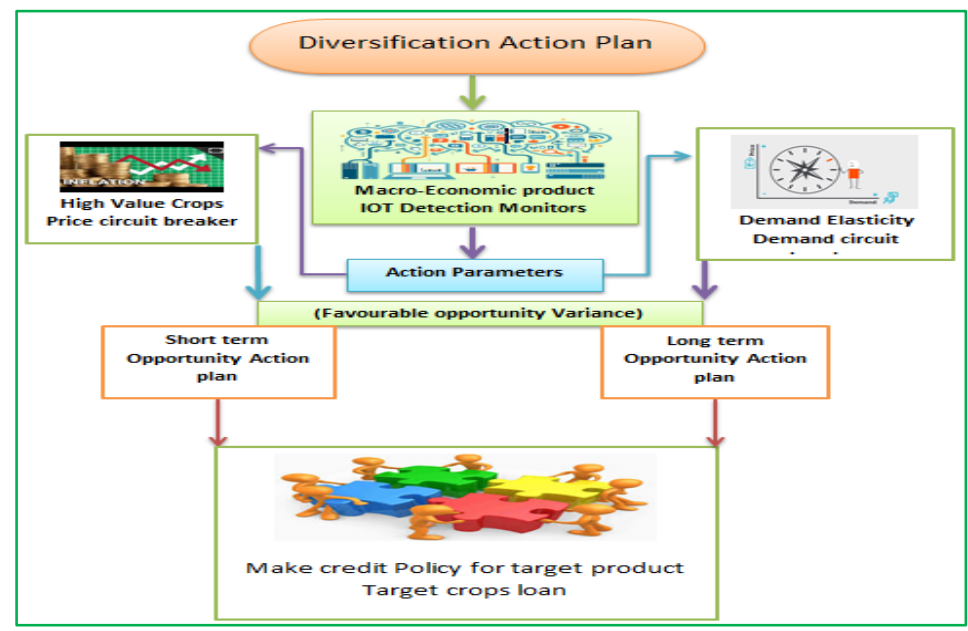

Figure 6 - Diversification Action Plan Model (Source: Authors compilation) 
This plan can be implemented through IOT (Internet of Things) technique, for execution of this plan; we have to make specific software according to macro-economic action plan requirement parameters. Parameters will includes Products price (High Value and low value products) and demand. Circuit price breakers and circuit demand breakers have to be determines for find out the opportunity information. Product wise import details have to monitor through this software. Segment wise production details also have to be maintaining in this software. This Execution plan will identify the two types of opportunity based information:

- Short Term Action Plan Opportunity;

- Long Term Action Plan Opportunity.

Software will be automatically forward information to policy making department. After revive the information, they department will prepare credit policy for the crops.

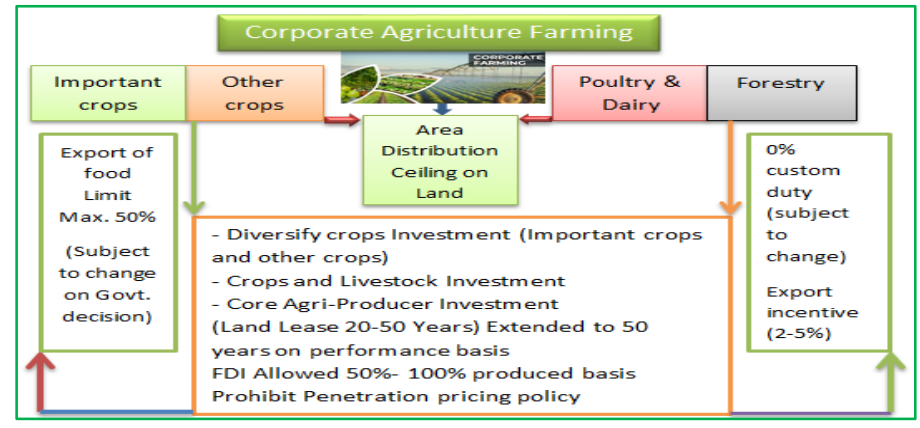

Figure 7 - Corporate Agriculture Farming Model Source (Source: Authors compilation)

After analyzing the primary and secondary data, it is clear that existing Corporate Agriculture Farming require some changes. From the table 2 finding reveals that the growth of agriculture is not consistent towards positive context. Majority of Corporate firm are focusing on important crops, cotton and livestock but they are ignoring other crops which are so much important for food security so due to concentration on specific crops, the other nutritious crops prices are going high and this hike in price are affecting the interest of poor people. This policy should be change on diversification basis. The below plan is diversified into all segment of agriculture. Investment should be on diversified basis. Land lease time should be 20-50 years. Export of food should be maximum 50\%. Investment diversification can be categorized into; Diversify crop Investment (Important and Other crops) subject to crops wise ceiling on land, Crops and livestock investment scheme, Core Agri product scheme. The entire scheme in this model prohibited penetration price policy of investors.

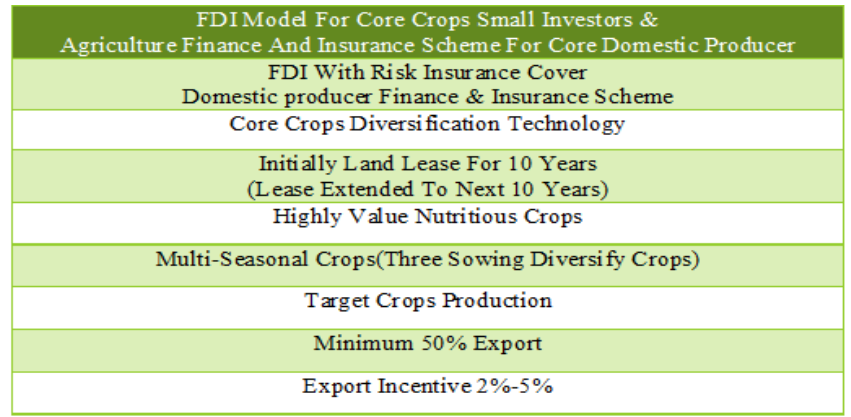

Figure 8 - FDI Model for Core Crops Producer Small Investor and Agriculture Finance and Insurance Scheme for Core Domestic Producer (Source: Authors compilation)

These two schemes especially for those products for which demand is high, high price products and production of these crops are always negative. We can invite the foreign small investors who have the core expertise to producing this product. These schemes will provide risk insurance cover to foreign investor. Even this scheme provides finance and insurance 
cover to domestic producer who have small landholding less than 25 acres. For domestic producer, this scheme will provide low interest finance. In this scheme land lease condition are two flexible, initially lease will be given for 10 to 20 years according to investor and it can be further extended for another 10 years. Only those producer who have core expertise past experience to sowing this crops, they can avail the benefit of this scheme. Target production condition will be the part of the scheme, if the producer will fail to achieve the minimum production license of investment will be withdrawn. This scheme is export oriented; exporter will get incentive on export of crops.

Agriculture start-up finance scheme for newly agriculture graduates. These following schemes will provide finance and other supports to fresh agriculture graduate they can become future entrepreneur in agriculture and they will contribute to GDP of the Pakistan through the uses of modern approach of farming:

- Agriculture start-up finance scheme for millets products (wheat, barley, maze etc.);

- Agriculture start-up finance scheme for vegetables and fruits products;

- Agriculture start-up finance scheme for poultry products;

- Agriculture start-up finance scheme for dairy products.

\section{CONCLUSION}

Pakistan's agricultural economy is going through its stagnant phase. In this paper, it has been attempted to know how the agricultural economy of Pakistan can be brought back. In this research, it has been envisaged that the food security requirements of Pakistan's growing population can be met by internal diversification and land reforms and these policies will be effective in the goal of inclusive development. The result of this research has come out that the internal diversification and land reform will prove to be a milestone in the agriculture of Pakistan. In this paper, some models have also been suggested in this regard which will prove to be very useful in internal diversification.

\section{REFERENCES}

1. Alur, A.S., Maheswar, D.L. (2018) "Crop Diversification - A strategy to Improve Agricultural $\quad$ Production", http://www.commodityindia.com/publication/magazine/web/Crop\%20Diversification\%20A\%20strategy\%20to\%20Improve\%20Agricultural\%20Production.html Accessed on $11 / 12 / 2018$.

2. Asian Development Bank (2018) "Pakistan: Economy" https://www.adb.org/countries/pakistan/economy Accessed on 02/12/2018.

3. Countries Studies (2018) AGRICULTURE http://countrystudies.us/pakistan/49.htm. Accessed on 03/12/2018.

4. Dawn (2010) "Land reforms in Pakistan" http://www.dawn.com/news/570487 Accessed on $07 / 12 / 2018$.

5. Dixit, P., Lal, R. C. (2019), "Inclusive Growth and Social Responsibility - A Critical Analysis of Indian Textile Industry", MERC Global's International Journal of Management, Vol. 7, Issue 2, pp. 202-210.

6. Dixit, P. and Lal, R. C. (2016) "Role of Gandhi's Khadi Textile Industry towards Inclusive Growth and Corporate Social Responsibility", Int. J. of Trade and Commerce-IIARTC, Vol. 5, No. 1, pp. 115-120, DOI 10.13140/RG.2.2.36573.26086.

7. Dixit, P., Tyagi, A. (2018) "A Study of Downturn Trends of Crude Oil Price - An Economic Advantage for Indian Government and Consumers" 10.13140/RG.2.2.27345.79207.

8. Mekuria, Wuletaw (2018) "Determinants of crop-livestock diversification in the mixed farming systems: evidence from central highlands of Ethiopia", https://agricultureandfoodsecurity.biomedcentral.com/articles/10.1186/s40066-018-02122 Accessed on 12/12/2018. 
9. Ministry of Finance (Pakistan) (April 18, 2018) Overview of the Economy http://www.finance.gov.pk/survey/chapters_18/overview_2017-18.pdf Accessed on 09/12/2018.

10. Ministry of information and broadcasting Pakistan (2017) "Highlights of Pakistan Economic Survey 2016-17", http://moib.gov.pk/day/highlights_of_pakistan_economic.pdf. Accessed on 11/12/2018.

11. Nation Encyclopedia (2018) "Pakistan - Agriculture", https://www.nationsencyclopedia.com/economies/asia-and-the-pacific/pakistanagriculture.html Accessed on 03/12/2018.

12. Pankaj, D., Lal, R. (2019). A Critical Analysis of Indian Textile Industry: An Insight Into Inclusive Growth And Social Responsibility. Russian Journal of Agricultural and SocioEconomic Sciences, 88(4), 53-61. doi:10.18551/rjoas.2019-04.08.

13. Pankaj, D., Ramyar, R. (2019). Diversification Of Economy - An Insight into Economic Development with Special Reference to Kurdistan's Oil Economy and Agriculture Economy. Russian Journal of Agricultural and Socio-Economic Sciences, 85(1), 395-404. doi:10.18551/rjoas.2019-01.48.

14. Pakistan Bureau of Statistics (2010) "Agricultural Census 2010 - Pakistan Report" http://www.pbs.gov.pk/sites/default/files/aco/publications/agricultural_census2010/writeup\%20agri.\%20census\%202010.pdf Accessed on 09/12/2018.

15. Shah, F. (2009) "Corporate farming: pros and cons for Pakistani economy" https://www.farmlandgrab.org/post/view/9588-corporate-farming-pros-and-cons-forpakistani-economy Accessed on 15/12/2018.

16. United Nation Climate Change (2018) "Economic diversification", https://unfccc.int/topics/resilience/resources/economic-diversification Accessed on 06/12/2018.

17. World Bank (Oct 05, 2018) The World Bank in Pakistan https://www.worldbank.org/en/country/pakistan/overview Accessed on 02/12/2018. 